\title{
Reducing Mould Risk During the Building Design Stage: Case Studies in South-East China
}

\author{
*Shenghuan Zhao and Enrico De Angelis
}

\begin{abstract}
Published online: 15 July 2020
To cite this article: Shenghuan Zhao and Enrico De Angelis (2020). Reducing mould risk during the building design stage: Case studies in South-East China. Journal of Construction in Developing Countries, 25(1): 1-20. https://doi.org/10.21315/ jcdc2020.25.1.1.
\end{abstract}

To link to this article: https://doi.org/10.21315/jcdc2020.25.1.1

\begin{abstract}
Indoor mould is usually discussed for the building operation phase rather than the design stage. Moreover, the majority of existing studies were conducted by mechanical engineers rather than architects, who typically have a broader view of the whole project. The purpose of this article is to obtain a quantitative mould risk scenario across the Yangtze River Delta in China and make a matrix including all the possible design options to reduce the mould risk. A series of software is utilised to simulate the mould risk in three main cities across that region. Simulation results confirm high mould risk in all selected cities and the mould growth rates in different orientations match the Wind-Driven Rain diagram. After the simulation, all factors that can be tuned for the mould prevention were analysed. It is found that only humidity and substrate (material of finishing layer) characteristics can be practically controlled for mould avoidance. Meanwhile, the development design stage is the essential design phase while the envelope is the most crucial building element for mould prevention.
\end{abstract}

Keywords: Moisture, Building envelope, Building science, Building design, Building pathology

\section{INTRODUCTION}

Due to its negative effect on occupants' health (Nunez and Hammer, 2014; Moon and Augenbroe, 2004), the indoor mould problem has received much attention from governments in many developed countries (American Society of Heating, Refrigerating and Air-Conditioning Engineers [ASHRAE], 2012; United States Environmental Protection Agency [US EPA], 2012; 2013). Nevertheless, there is no code in China specifically mentioning or offering instructions on indoor mould prevention. Even design codes for hospitals and schools, which actually should require a higher indoor air quality, states nothing on this issue. All of this does not mean mould-free in China. The Yangtze River Delta (black colour filled in Figure 1), including the Shanghai municipality and two nearby provinces, is known as the most mould-vulnerable place in the country. A survey (Wei, 2016) indicated that more than half of the investigated families in Shanghai had an indoor mould problem. The primary cause may be the rainy season called Plum Rain Season from June to July each year. Everything during that period becomes extremely mouldvulnerable because of the highest annual temperature and humidity. Meanwhile, the fruit plums, sharing the same pronunciation of mould in Chinese, ripen and fall from trees like a plum rain. Ancient habitants replaced the word mould with plum to make that period not so annoying but a little bit poetic (Baidu.com, 2016).

Department of Architecture, Built Environment and Construction Engineering, Politecnico di Milano, Milan, ITALY

"Corresponding author: shenghuan.zhao@polimi.it 


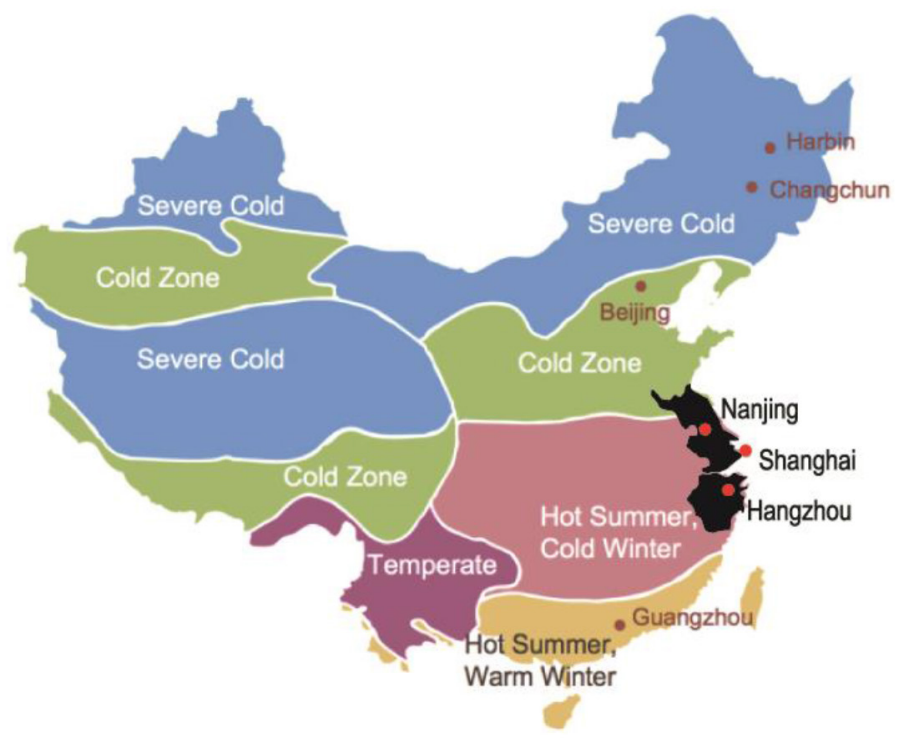

Figure 1. Location and Climate Zone Information of Three Cities (Elaborated by the Authors)

It is time and money consuming to remediate a wall after the mould appearance (Moon and Augenbroe, 2004). Moreover, many building design decisions influencing indoor air quality (IAQ) are hard to be revised after the early design stage (ASHRAE, 2009). Therefore, the mould risk should be proactively considered since the design starts. Nevertheless, the majority of related studies are done by mechanical engineers who only focused on the heating, ventilation and air conditioning (HVAC) system without considering all the design options. The correlation between building design and the mould risk is rarely discussed in the literature. It means that there are more ignored design opportunities can be utilised for mould prevention.

This article tries to diagnose the wall mould-vulnerability by computational simulation where: (1) hygrothermal condition (moisture and temperature) on the wall inner surface will be simulated first, (2) the water content in spores will be calculated according to the previous simulation and (3) the mould growth rate and mould index will be computed based on the spore situation. Afterwards, all the design strategies for mould-prevention are scrutinised and integrated along the design workflow. In the end, a matrix identifying possible design chances for mould prevention is presented. Due to the complexity of the building as a system, the current study is impractical to be validated by on-site experiments. However, this investigation still has noteworthiness with its effort on connecting the building science with architects. It could be beneficial to architects who frequently ignore or have no idea how to consider the indoor mould problem and it is also useful for policymakers to make more scientific design guides. 


\section{MOULD RISK DIAGNOSING}

\section{Selected Cities and Their Climates}

Three main cities (as shown in Figure 1) across the Yangtze River Delta are observed locations: Hangzhou (capital of Zhejiang provenience), Shanghai (special municipality) and Nanjing (capital of Jiangsu provenience). Three cities are all located in the hot summer-cold winter climate zone (as shown in Figure 1) and share similar climates (as shown in Table 1). Data in Table 1 is retrieved from software Meteonorm (Meteotest AG Company, Bern, Switzerland) and WUFI ${ }^{\circledR}$ Pro, which will be introduced later. The most distinctive meteorology aspect is the Annual WindDriven Rain: Hangzhou has the most rain from the south-east, Shanghai maximises the rain gain in $22.5^{\circ}$ east of south, while Nanjing obtains the majority rain in the south. Other geology and climate information, such as temperature, also can be found in Table 1.

\section{Wall Structures Selected for Simulation}

To reduce energy consumption in the building sector, the central and local governments published a series of atlases on energy-efficient wall compositions. Wall types investigated herein are all from these official atlases (listed in the second row of Table 2). Hangzhou and Nanjing have their local atlases while the one used for Shanghai is a national one. The one Zhejiang proposed is self-insulation typology while the other two provinces have individual insulation layers. Property indices of core materials (Layer 4 for Hangzhou, Layer 6 for Shanghai and Nanjing) are stated in those atlases. However, Layer 1 to Layer 3 in Table 2 are not included in any atlas but are the most common internal-surface composition across the Yangtze River Delta. Materials not found in official recommendations are replaced by similar things from the WUFI ${ }^{\circledR}$ software database (Fraunhofer Institute for Building Physics, Bavaria, Germany) (as shown in Table 3). 
Shenghuan Zhao and Enrico De Angelis

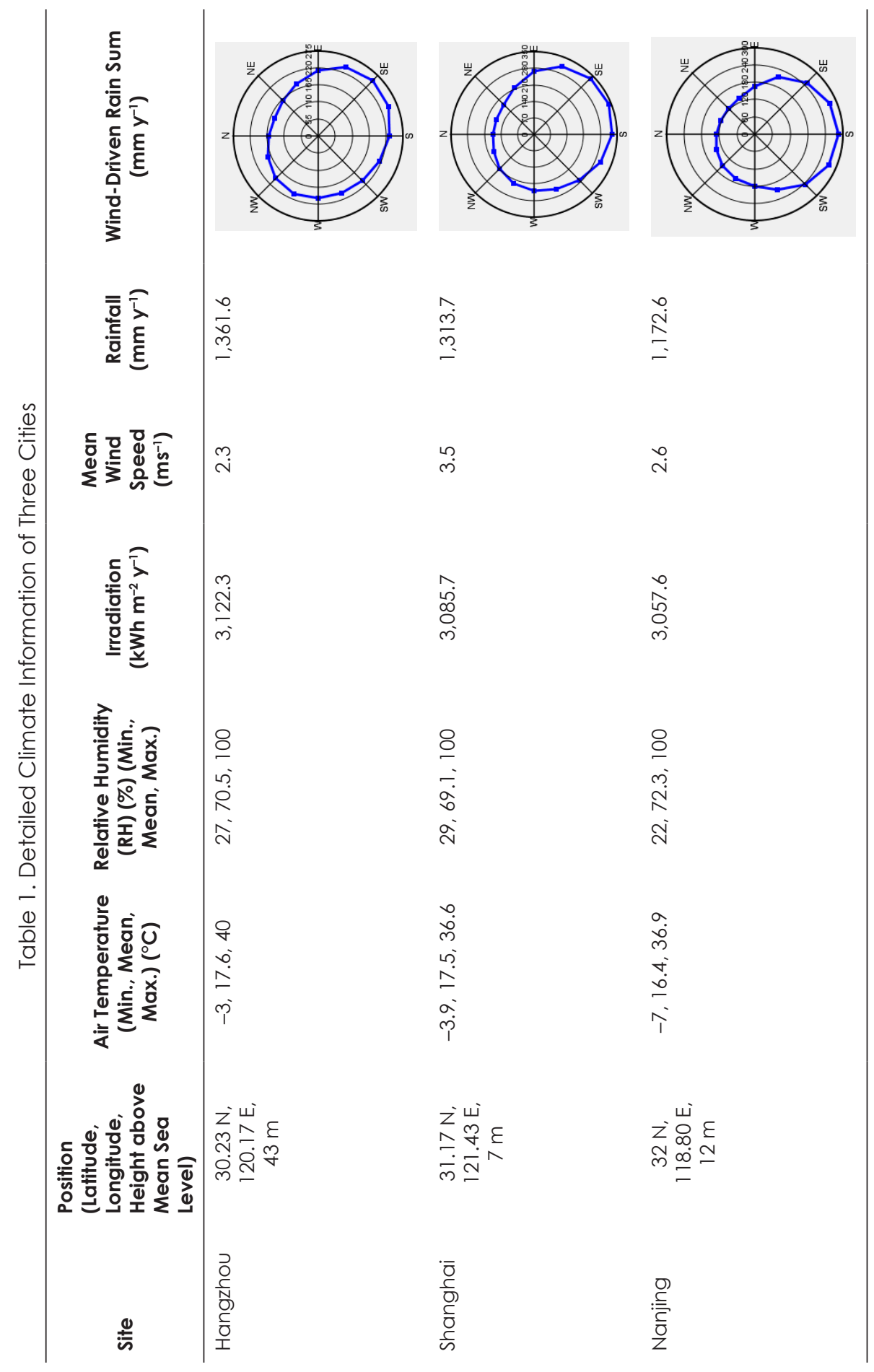


Table 2. Sources and Composition of Three Multilayer Walls (from Internal to External)

\begin{tabular}{|c|c|c|c|c|c|}
\hline \multicolumn{2}{|c|}{ Hangzhou } & \multicolumn{2}{|c|}{ Shanghai } & \multicolumn{2}{|c|}{ Nanjing } \\
\hline \multicolumn{2}{|c|}{$\begin{array}{l}\text { Integral structure and } \\
\text { energy saving of lightweight } \\
\text { concrete block wall }\end{array}$} & \multicolumn{2}{|c|}{$\begin{array}{l}\text { Atlas of the assembled } \\
\text { monolithic residential } \\
\text { structures }\end{array}$} & \multicolumn{2}{|c|}{$\begin{array}{l}\text { External insulation system } \\
\text { with heat resisting (HR) } \\
\text { decorative insulation } \\
\text { board }\end{array}$} \\
\hline $\begin{array}{l}\text { Names of } \\
\text { Materials }\end{array}$ & $\begin{array}{l}\text { Thickness } \\
(\mathrm{mm})\end{array}$ & $\begin{array}{l}\text { Names of } \\
\text { Materials }\end{array}$ & $\begin{array}{l}\text { Thickness } \\
(\mathrm{mm})\end{array}$ & $\begin{array}{l}\text { Names of } \\
\text { Materials }\end{array}$ & $\begin{array}{l}\text { Thickness } \\
(\mathrm{mm})\end{array}$ \\
\hline Latex painting & 3 & Latex painting & 3 & $\begin{array}{l}\text { Latex } \\
\text { painting }\end{array}$ & 3 \\
\hline Gypsum plaster & 8 & Gypsum plaster & 8 & $\begin{array}{l}\text { Gypsum } \\
\text { plaster }\end{array}$ & 8 \\
\hline Mixed mortar & 20 & Mixed mortar & 20 & $\begin{array}{l}\text { Mixed } \\
\text { mortar }\end{array}$ & 20 \\
\hline $\begin{array}{l}\text { Lightweight } \\
\text { concrete blocks } \\
\text { (HQLCB240950) }\end{array}$ & 240 & $\begin{array}{l}\text { Concrete blocks } \\
\text { (Two rows of } \\
\text { holes) }\end{array}$ & 190 & $\begin{array}{l}\text { Concrete } \\
\text { blocks } \\
\text { (Two rows of } \\
\text { holes) }\end{array}$ & 190 \\
\hline Cement mortar & 20 & Cement mortar & 20 & $\begin{array}{l}\text { Cement } \\
\text { mortar }\end{array}$ & 20 \\
\hline Gypsum plaster & 8 & $\begin{array}{l}\text { Expanded } \\
\text { polystyrene } \\
\text { board (EPS) } \\
\text { insulation panel }\end{array}$ & 90 & $\begin{array}{l}\text { HR } \\
\text { decorated } \\
\text { insulation } \\
\text { panel }\end{array}$ & 30 \\
\hline Facial brick & 12 & Facial brick & 12 & $\mathrm{~N} / \mathrm{A}$ & N/A \\
\hline Total thickness & 311 & Total thickness & 343 & $\begin{array}{l}\text { Total } \\
\text { thickness }\end{array}$ & 271 \\
\hline U-value & 0.896 & U-value & 0.199 & U-value & 0.166 \\
\hline
\end{tabular}

Source: Zhejiang Provincial Department of Housing and Urban-Rural Development (2013), Shanghai Commission of Urban and Rural Construction and Transportation (2013) and Jiangsu Provincial Office for Construction Engineering Standards (2006) 
Table 3. Properties of Three (Self-) Insulation Materials and the External Coating Layer

\begin{tabular}{|c|c|c|c|c|c|}
\hline $\begin{array}{l}\text { Name of } \\
\text { Materials }\end{array}$ & $\begin{array}{l}\text { Density } \\
\left(\mathrm{kg} \mathrm{m}^{-3}\right)\end{array}$ & $\begin{array}{l}\text { Conductivity } \\
\left(\mathrm{W} \mathrm{mk} \mathrm{m}^{-1}\right)\end{array}$ & $\begin{array}{l}\text { Water } \\
\text { Vapour } \\
\text { Resistance } \\
\text { Factors }\end{array}$ & $\begin{array}{l}\text { Typical } \\
\text { Built-in } \\
\text { Moisture } \\
\left(\mathrm{kg} \mathrm{m}^{-3}\right)\end{array}$ & $\begin{array}{l}\text { Specific } \\
\text { Heat } \\
\text { Capacity } \\
\left(\mathrm{J} \mathrm{kg}^{-1} \cdot \mathrm{K}\right)\end{array}$ \\
\hline $\begin{array}{l}\text { Lightweight } \\
\text { concrete blocks } \\
\text { (HQLCB240950) }\end{array}$ & 1,250 & 0.27 & $80^{*}$ & $200^{*}$ & $850^{*}$ \\
\hline $\begin{array}{l}\text { EPS insulation } \\
\text { panel }\end{array}$ & 18 & 0.041 & 30 & 0.13 & 1,500 \\
\hline $\begin{array}{l}\text { HR decorated } \\
\text { insulation panel }\end{array}$ & 20 & 0.03 & $3.4^{*}$ & $4.5^{*}$ & $850^{*}$ \\
\hline Facial brick & 3,000 & 0.6 & $9.5^{*}$ & $30^{*}$ & $850^{*}$ \\
\hline
\end{tabular}

Notes: *Values from similar products in the WUFI database

Source: Zhejiang Provincial Department of Housing and Urban-Rural Development (2013), Shanghai Commission of Urban and Rural Construction and Transportation (2013) and Jiangsu Provincial Office for Construction Engineering Standards (2006)

\section{Software Introduction and Boundary Settings}

\section{Meteonorm and WUFI ${ }^{\circledR}$}

The broadly used climate data format EPW (EnergyPlus Weather File format) does not contain the rain data, which is crucial for the mould risk simulation. Therefore, climate datasets used herein are from software Meteonorm. Although data from Meteonorm is not measured onsite but converted from surrounding statistics, it has been validated very close to reality (Häglund, Isaksson and Thelandersson, 2010). For settings in the Meteonorm, radiation period is from the year 1991 to the year 2010 while the base temperature is from years 2000 to 2009. These two options are closest to the current date. Intergovernmental Panel on Climate Change (IPCC) Scenario for future periods is picked with the Bl mode, which hypothesises a rapid economic growth and stable economic, social and environmental situation.

A set of $\mathrm{WUF}^{\circledR}$ software, which has been validated by several experimental examinations (Sedlbaver, 2001a), is used for the mould risk prediction. The whole simulation includes two steps (as shown in Figure 2): WUFl $^{\circledR}$ Pro simulates the hygrothermal condition, then the water content of spores and the associated mould risk are calculated by WUFI ${ }^{\circledR} \mathrm{BIO}$. The latest software WUFI ${ }^{\circledR} \mathrm{VTT}$ which has the similar function as $\mathrm{WUFI}^{\circledR} \mathrm{BIO}$ is also used for the mould index prediction in parallel.

Hygrothermal calculation models of simulation software can be categorised as "envelope models" and "models within a whole building simulation" (Moon and Augenbroe, 2003). The first kind of models is unable to consider dynamical sources like the HVAC system, internal latent loads like heat radiance from occupants, nor transient hygrothermal behaviour. For this reason, they offer less realistic results than the second category models which take into account sources like the HVAC system (Moon and Augenbroe, 2003). Belonging to the first category, the numerical model in software WUFI ${ }^{\circledR}$ Pro only assumes a steady-state thermal environment. The simulated position is the other drawback. WUFI ${ }^{\circledR}$ Pro can only monitor the wall 
surface rather than the joint places between wall and wall or wall and window, which are more mould vulnerable due to the thermal bridge.

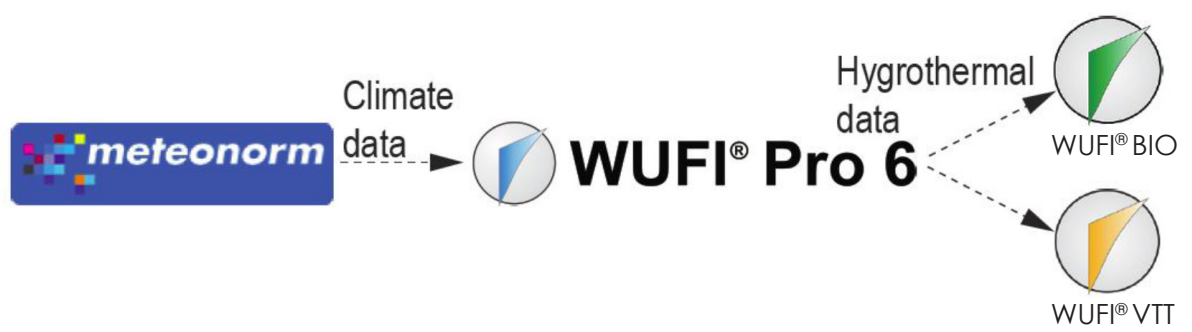

Figure 2. Software Architecture for the Simulation Process

For the mould risk prediction models, there are more options besides the $\mathrm{WUFI}^{\circledR} \mathrm{VTT}$ and $\mathrm{WUFI}^{\circledR} \mathrm{BIO}$. More specific information regarding calculation models can be found in the review made by Vereecken and Roels (2012). In this study, these two models were selected because they are available for free access. The main difference between them is that WUF ${ }^{\circledR}$ VTT considers the growth diminish after longer dry periods while WUF ${ }^{\circledR} \mathrm{BIO}$ does not (Fraunhofer Building Innovation, 2017). Meanwhile, results from both software only identify the situation on the wall inner surface, which is another limitation of the present study.

\section{Boundary settings}

A six-storey building (around $18 \mathrm{~m}$ ) with common residential typology is hypothesised for this simulation. Building walls are fully vertical and below a low-slope roof. The rain exposure category is medium and the rain load predication is based on ASHRAE Standard 160. According to a national regulation from the General Office of the State Council (2007), the indoor temperature of buildings in China must be above $26^{\circ} \mathrm{C}$ in summer and below $20^{\circ} \mathrm{C}$ in winter. So, $26^{\circ} \mathrm{C}$ is assumed as the summer indoor temperature, $20^{\circ} \mathrm{C}$ for winter and $23^{\circ} \mathrm{C}$ as the annual average value. Mentioned in the code "Designing Energy-Efficient Residential Buildings in Hot Summer and Cold Winter Zone" (Ministry of Housing and Urban-Rural Development, 2010), the ventilation rate must be higher than $1.0 \mathrm{~h}^{-1}$ when the air conditioning is at work (summer). For the calculation period, it is set for five years, from the year 2018 to 2022. The same annual weather file from Meteonorm is used for these five years. All things mentioned previously are inputs required by the WUF ${ }^{\circledR}$ Pro but it becomes difficult to choose the orientation for simulation because of the orientation selection in WUF ${ }^{\circledR}$ associates with other factors influencing mould risk such as: (1) solar incident radiation (on the outdoor surface), (2) Wind-Driven Rain and (3) convective heat transfer coefficient (a step-function of wind direction).

Therefore, it is not clear which orientation would be the most mouldvulnerable. Rather than randomly picking one, all eight orientations offered by WUF ${ }^{\circledR}$ Pro are going to be simulated. According to the yearly mould growth rate in all orientations which will be simulated later (as shown in Table 4), south-east is the most mould-vulnerable direction for all three cities. Therefore, the simulation process will be illustrated in this orientation. 


\section{RESULTS AND DISCUSSIONS}

\section{Hygrothermal Condition and the Water Content in Spores}

The outcome of hygrothermal simulation (as shown in Figure 3) includes the temperature and humidity condition over five years. The X-axis is the time in the unit of hour and the $Y$-axis stands for the relative humidity and temperature, respectively. From June to August each year (the rainy season), the relative humidity in three cities reaches the absolute maximum value. It is higher than the critical threshold of $80 \%$ which was recommended by the International Energy Agency (IEA) for preventing mould germination (Hens, 1992). Due to the mean humidity in the three cities is around $70 \%$, so the relative humidity can easily reach $80 \%$. The hygrothermal condition of Shanghai and Nanjing are similar, identified by two nearly overlapped charts. The humidity of Hangzhou is higher and fluctuates more drastically at the bottom of the chart. For temperature, Shanghai and Nanjing still stay similar with little variation, while Hangzhou still swingers bigger but lower than the other two.

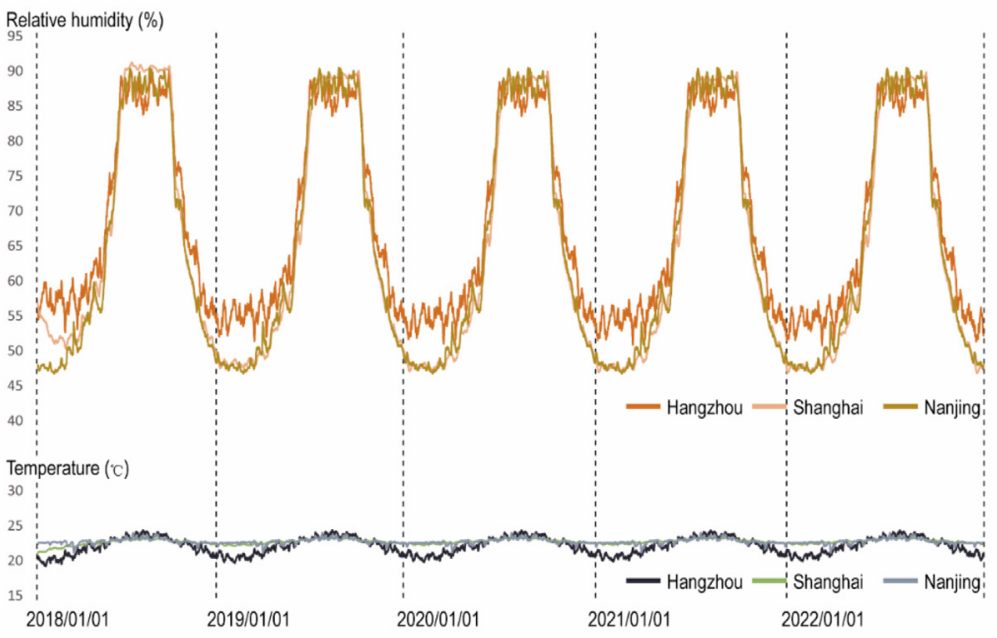

Note: Coloured version of this figure is available in the online edition of Journal of Construction in Developing Countries.

Figure 3. Hygrothermal Situation on Inner Surface

Based on hygrothermal simulation results, WUF ${ }^{\circledR} \mathrm{BIO}$ calculates the water content in spores. For settings in the $\mathrm{WUFI}^{\circledR} \mathrm{BIO}$, the initial relative humidity is $50 \%$ while the substrate belongs to the Class I. Obtained outcomes (as shown in Figure 4) show that the Plum Rain Season is a crucial period for the water content each year. Starting from the June (the beginning of the rainy season), the water content of spores in all three walls rise speedily and overwhelmingly exceed the critical water content, which is only around $200 \mathrm{~kg} \mathrm{~m}^{-3}$. They stay steady until September and drop fast after that. Comparing the apex period of the three cities, Shanghai is the highest and Nanjing is the second highest. Hangzhou has the least water content in spores but this number fluctuates more intensely. 


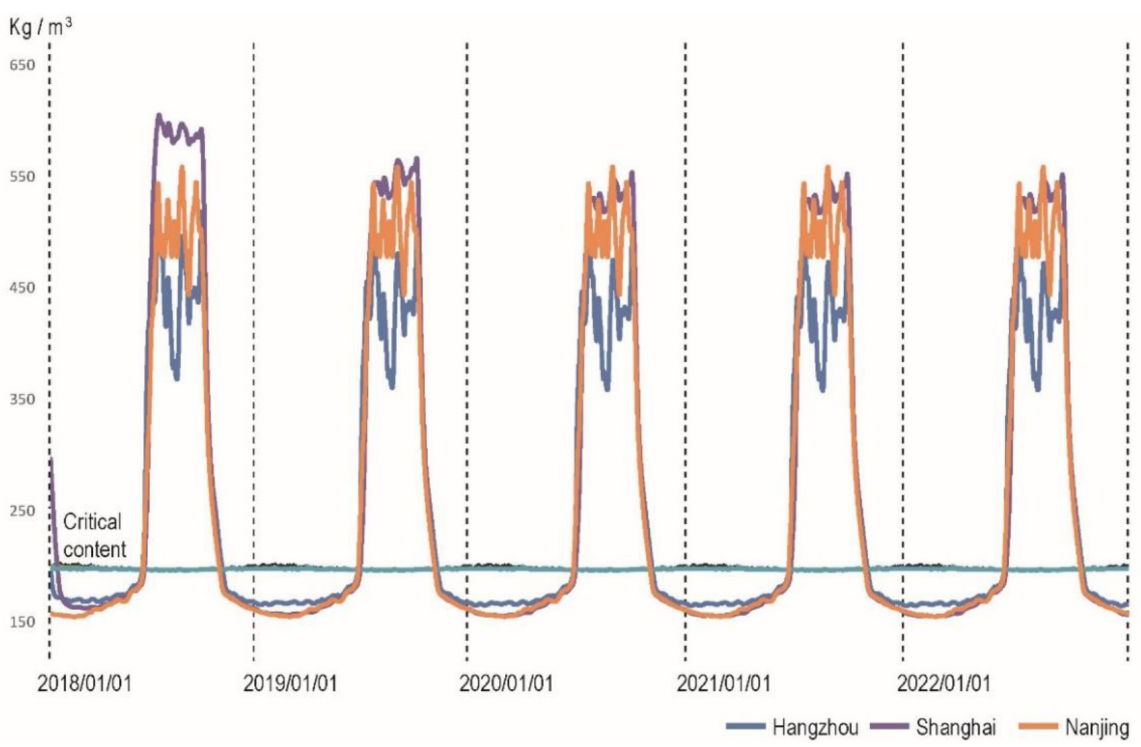

Note: Coloured version of this figure is available in the online edition of Journal of Construction in Developing Countries.

Figure 4. Water Content in Spores

\section{Mould Growth Rate and Mould Index}

After receiving results of water content in spores, the mould growth rate is simulated with the WUFI ${ }^{\circledR} \mathrm{BIO}$ and WUFI ${ }^{\circledR}$ VTT. Table 4 demonstrates the mould growth rate of all eight orientations and these statistics are visualised in a radar chart (as shown in Figure 5). South-east is the most mould-vulnerable orientation for all cities and all radar diagrams match pictures of Wind-Driven Rain orientation (included in Table 1).

Hangzhou has the highest time-average mould growth rate around $296 \mathrm{~mm}$ per year, the number of Shanghai is $438 \mathrm{~mm}$ per year and Nanjing has about 273 $\mathrm{mm}$ per year. However, the lowest mould growth rates in three cities all exceed $200 \mathrm{~mm}$ per year, which means none of the wall typologies is acceptable in the perspective of mould risk.

Table 4. Mould Growth Rate Simulated by WUFI ${ }^{\circledR}$ BIO (mm per year)

\begin{tabular}{lcccccccc}
\hline & North & $\begin{array}{c}\text { North- } \\
\text { West }\end{array}$ & West & $\begin{array}{c}\text { South- } \\
\text { West }\end{array}$ & South & $\begin{array}{c}\text { South- } \\
\text { East }\end{array}$ & East & $\begin{array}{c}\text { North- } \\
\text { East }\end{array}$ \\
\hline Hangzhou & 287 & 291 & 291 & 292 & 295 & 296 & 293 & 289 \\
Shanghai & 435 & 436 & 437 & 437 & 438 & 438 & 437 & 436 \\
Nanjing & 269 & 271 & 271 & 271 & 272 & 273 & 272 & 270 \\
\hline
\end{tabular}



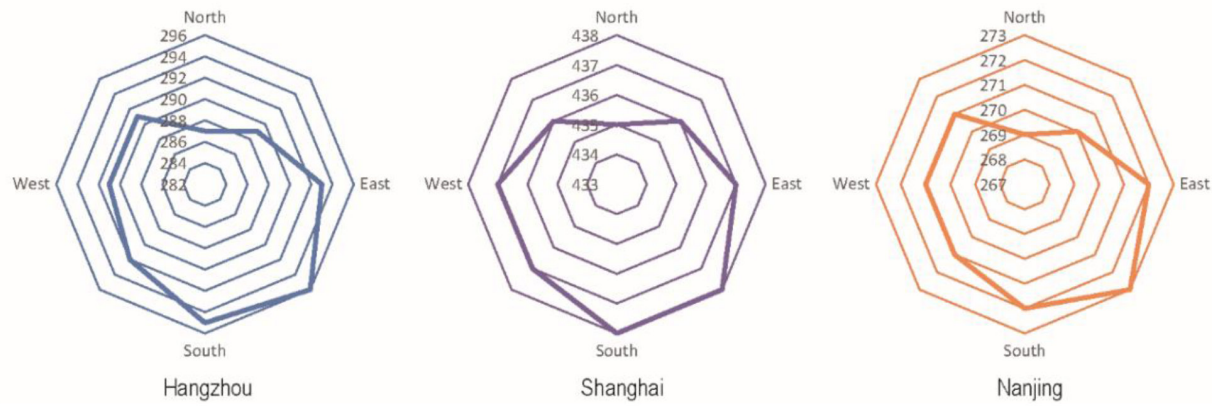

Figure 5. Mould Growth Rate in Different Orientations of All Three Cities

The mould index was initially coined by Viitanen and Ritschkoff (1991) to identify the mould problem more clearly. They divided the mould condition into six levels: Level Zero means no mould at all, the growth process starts from Level One but only can be perceived with the microscope, the mould coverage in Level Two reaches $10 \%$ of the surface, mould growth in the Level Three is visible to the unaided eye, the coverages reach 10\%, 50\% and 100\% from Level Four to Level Six, respectively.

In three testing cities, all the mould indexes have risen drastically since the first year June and arrive at a plain at the end of September (as shown in Figure 6). Shanghai has the highest mould index over the five years and stays still at 3.7. Hangzhou has a steep decrease at the beginning of the year 2019 but staying steady at the mould index of 3. Nanjing is lower than Hangzhou during the first year but staying higher for the left four years. As what was introduced before, WUFI ${ }^{\circledR} \mathrm{BIO}$ does not consider the unfavourable period but WUFI ${ }^{\circledR}$ VTT does. However, there is an observable decrease in Figure 6. This outcome might have resulted from the competition in the mould group itself. The nutrition consumption speed does not support the mould staying at the same level.

Based on a different calculation model, simulation results in WUFl ${ }^{\circledR}$ VTT (as shown in Figure 7) are more favourable than results in the WUFI ${ }^{\circledR} \mathrm{BIO}$. For settings in the WUFI ${ }^{\circledR} V T T$, the building material is in the relatively low decline class with a cleaned type of surface. The sensitivity class is set as medium resistant. Except for the mould index of Shanghai, which still exceeds 2, which is unacceptable, both Nanjing and Hangzhou become less serious. The number of Nanjing is around 1.7 while Hangzhou has the lowest index at 1.5. All three cities have the turning point at the end of the September each year when the mould index starts decreasing before the rainy season in the next year.

Meanwhile, Shanghai has the highest mould index in both WUFI ${ }^{\circledR} \mathrm{VTT}_{\mathrm{T}}$ and WUFI ${ }^{\circledR}$ $\mathrm{BIO}$. Nanjing is also higher than Hangzhou in the numbers shown by the two softwares. It is a validation of two calculation models behind the software. Simulation results confirm that the national wall composition atlas is not suitable for local building in Shanghai. That type of wall composition has a vast possibility to bring indoor mould. Though the other two cities have their own locally official recommendations, the mould risk brought by the external wall is still lack of consideration and exploration. 


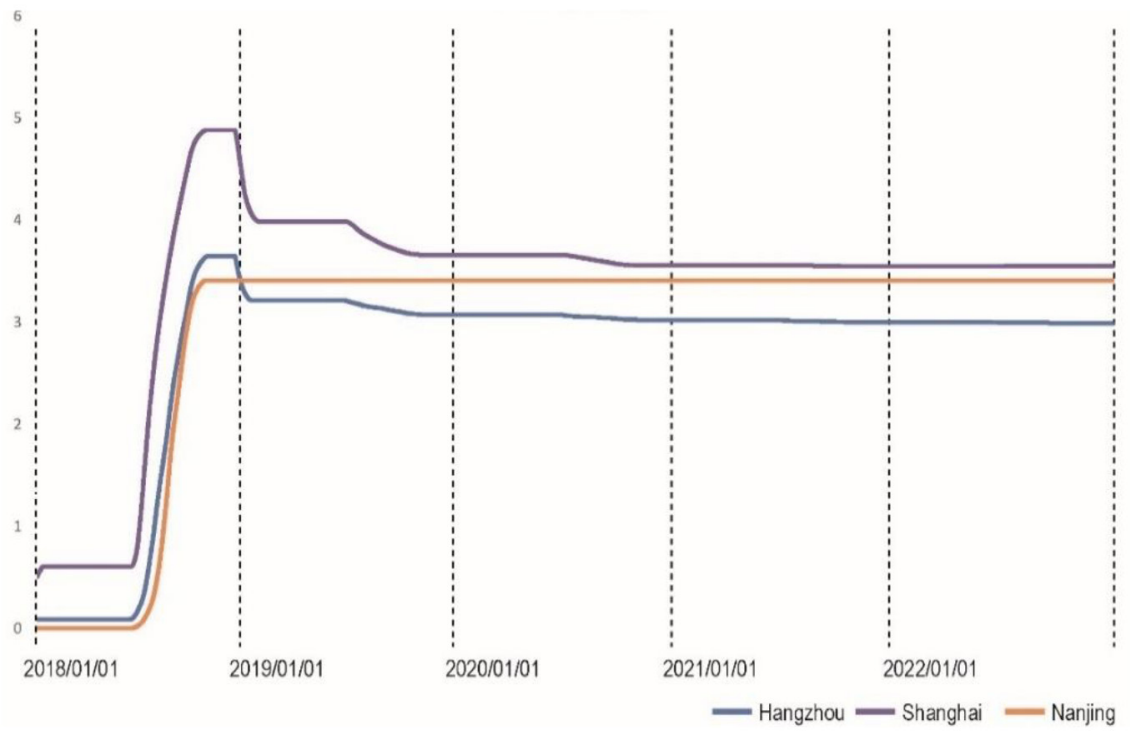

Note: Coloured version of this figure is available in the online edition of Journal of Construction in Developing Countries.

Figure 6. Mould Index of Three Cities within the South-East Orientation (by WUFI ${ }^{\circledR} \mathrm{BIO}$ )

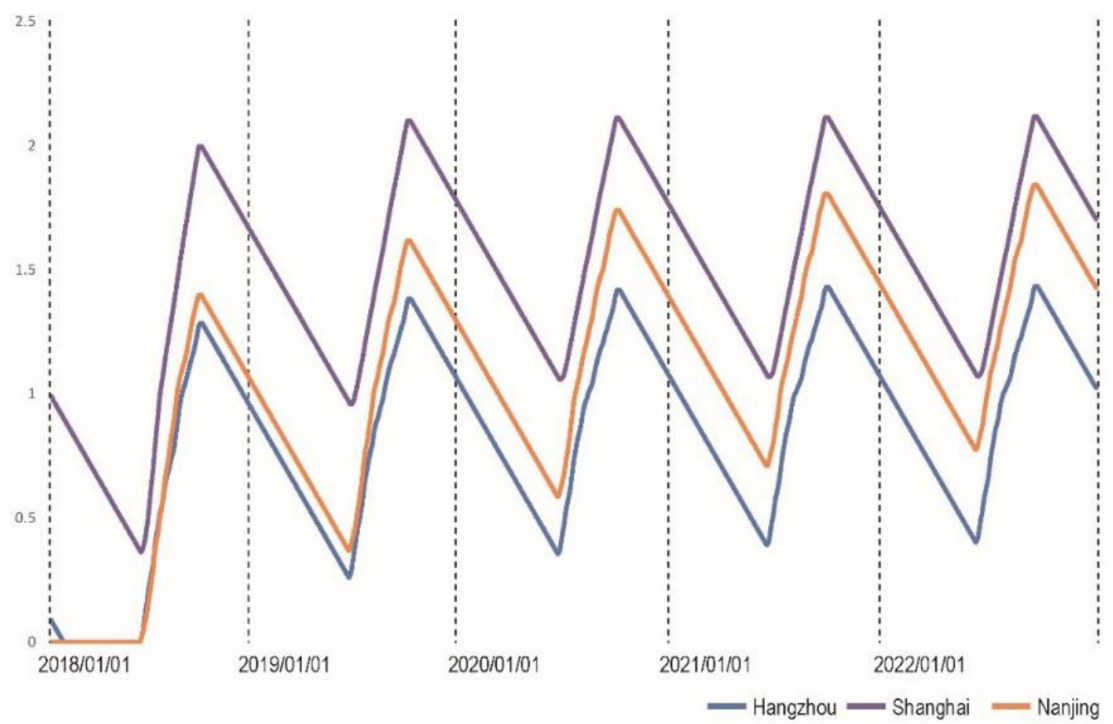

Note: Coloured version of this figure is available in the online edition of Journal of Construction in Developing Countries.

Figure 7. Mould Index of Three Cities within the South-East Orientation (by WUFI ${ }^{\circledR}$ VTT) 


\section{REDUCING THE MOULD RISK DURING DESIGN STAGE}

\section{Overall Consideration}

An effective workflow is critical to gain desirable indoor air quality (ASHRAE, 2009). Although numerical models and software like WUFI ${ }^{\circledR}$ exist to predict the mould risk, they only can verify the final design which has all decision variables decided, rather than helping the decision making during the design process. Meanwhile, it is impossible to quantify every design step because the majority of design decisions are made with qualitative considerations. Therefore, this section tries to embed all strategies in different design steps and make a guiding matrix to guide architects.

To reduce the mould risk during the design stage, inducing variables should be correlated to design strategies first. From nine variables proposed by Hens (2003), Sedlbaver (2001a) deemed only four main ones are impacting on indoor mould: temperature, humidity, substrate and exposure time in the critical hygrothermal condition (easy for the spore germination). Since more essential design objectives (thermal comfort, internal heat gain and user habits) decide the internal surface temperature, normally it is illogical to change the surface temperature for the mould prevention, except in special cases like rooms for surgery or preserving ancient books. Exposure time is another critical parameter for mould risk (Vereecken and Roels, 2012) because building construction materials exposing to a high humidity environment for a short period will not result in fungal growth if the previous period at low humidity is long enough (Viitanen et al., 2010; Møller et al., 2017). However, the exposure time is difficult to be correlated with design choices except that the inner surface of frequently-water-spilt rooms (showering rooms, toilets and laundry rooms) should be waterproofed, in order to wipe the water easily for changing the exposure time. Therefore, we can assume that temperature and exposure time are not practically tuneable to avoid mould in real design projects.

Not strongly driven by other more priority design objectives, only humidity and substrate characteristics (mainly refers to the mould-resistant ability) can be practically tuned for mould avoidance. As shown in Figure 8, the humidity consideration is related to more design chances. In accordance with different duties, design strategies associated with the humidity can be categorised into: lead the water away from the project site, keep the rest of water out of the building and limit the mould growth while moisture dries out (make it less prone to moisture retention or mould growth) (Harriman and Neil, 2006). For the material (substrate) selection, it is majorly based on the envelope design. Detailed relationships will be discussed in the following subsections.

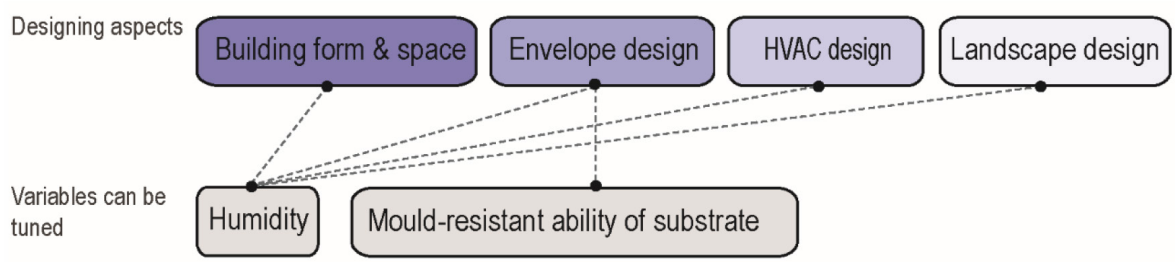

Figure 8. Relationship between Designing Aspects and Variables for Mould Reduction 


\section{Building Form and Space Design}

WUF ${ }^{\circledR}$ Pro requires two factors of building geometry as inputs: (1) building height and (2) wall inclination. They do influence the mould formation, for example, the higher building receives more Wind-Driven Rain (Karagiozis and Hadjisophocleous, 1995). However, both the building height and the wall inclination cannot be considered for the mould-free design. For real construction projects, they are decided by more important objectives like making more spaces for financial profit, rather than mould avoidance. This issue also identifies the importance of the current study which aims to connect the building science and building design. Traditional investigations were only studied in the scope of mould risk but neglecting the reality of a design project, which is driven by many other objectives.

Comparing with these two factors, the roof design, which conveys precipitation to the drainage system, is more viable for mould prevention. When we design the roof shape, the total rainfall volume should be carefully calculated before considering the rain diversion routine and also the roof inclination. On top of that, the distance of roof overhangs also should be deliberately computed because sometimes they can cut more than $50 \%$ of the water streaming down to a wall (Harriman and Neil, 2006).

In addition to the roof, the mould risk is also influenced by the building entrance which connects the internal space and the external weather. Therefore, a transitional zone like a closed porch or vestibule is necessary for some extremely damp areas, because of the drastically internal humidity change once the door is opened. To take away the extra moisture during the interior space design, the uniformity of the layout from floor to floor, space usage, which affects air distribution and ventilation, should be taken into account. Meanwhile, the irregular or trivial form should be avoided in case of the water retention on them. On the other side, according to the contact angle between a water drop and the surface, details like the roof drip-edge can be deliberately designed to facilitate the water dropping down (Rose, 2005). Not only are the details in the design itself but mistakes coming from workmanship also crucial to be considered. Therefore, the design also should be easily understood and constructed.

\section{Envelope Design}

\section{Decrease the humidity with envelope design}

When the facade is facing the water-landscape, architects like large windows or balconies opened into the water-landscape for desirable views. However, this kind of fenestration also brings a higher airborne moisture load which may lead to the indoor mould. Therefore, the operable area of a window should be carefully considered. Directly blocking the external moisture can be achieved not only by less opening area, but the vapour retarder also plays a vital role in it (Trechsel and Bomberg, 2010). The majority of buildings across the Yangtze River Delta have vapour retarders only for the roof and the basement, other than on facades. Thence, the water retarder can be added to reduce the mould risk in critical occasions. Nevertheless, water retarders containing hydrocarbons are easy to be evaporated over hot weather that can lead to cracking and leakage, which will be the main channels of moisture transportation (Rose, 2005). 
On top of the vapour retarder, the insulation layer is another cause of extra-moisture (Orlik-Kozdoń and Steidl, 2017). Due to different hygroscopic characteristics, some insulation materials absorb more moisture than others and results in different relative humidity. After being humidified one hour per day for 10 days, the relative humidity increased $5 \%$ in houses insulated by cellulose and boosted $30 \%$ in the house insulated with mineral wool (Mlakar and Štrancar, 2013). Insulation layer also strongly relates to the condensation which brings the water formation. The condensation resistance factor $\left(f_{\text {Rsi }}\right)$ was proposed by IEA to check the condensation risk (Hens, 1992). The value of $f_{R s i}$ is mainly decided by the thermal resistance of the total envelope and the internal finishing layer. Many countries other than China have their requirements on $f_{R S i}$ to avoid the condensation: $f_{0.2} \geq$ 0.7 in Belgium, $f_{R S i} \geq 0.65$ in Netherland and $f_{R S i} \geq 0.7$ in German. If the condensation appears on thermal bridges, insulating rendering coat can be applied to reduce the mould risk (Fantucci et al., 2017).

Condensation not only happens on the insulation layer but also occurs on the facade finishing layer. Due to its heat capacity has a substantial impact on the envelope temperature fluctuation, the finishing layer on facades is closely associated with the condensation (Elisa, 2013) which leads to mould. Especially on the surface of the northern wall, heat capacity is the most influential factor for mould growth because of condensation (Johansson, Wadsö and Sandin, 2010). Johansson, Wadsö and Sandin (2005) found that the nocturnal temperature on the finishing layer with high thermal capacity was $0.5 \mathrm{~K}$ higher than on the surface with low heat capacity which means lower condensation risk and mould risk for the material with high heat capacity. Besides the heat capacity, the hydrophilic property also should be considered when selecting the finishing layer.

Increasingly raised envelope-airtightness aimed to improve building energy efficiency is another cause of the extra indoor moisture. The raised airtightness creates new ways of heat and moisture transportation, which block the internal moisture passing through the envelope (Elisa, 2013). Nevertheless, in winter the Yangtze River Delta does not offer central heating, so the airtightness only contributes during the cooling period when the air conditioning is at work. Moreover, many buildings need higher air leakage rate due to no mechanical ventilation, thence the airtightness of building envelope in the Yangtze River Delta may not need to be as high as in other areas.

\section{Increase materials' ability to mould-resistant}

Selecting mould-resistant materials is the other approach to reduce mould risk during the envelope design. Many construction products are organically made to be environmentally friendly but that also makes them good substrates for the mould growth. For instance, common glve and wallpaper are desirable substrates for the majority of indoor fungal (Khan and Karuppayil, 2012; Hyvärinen et al., 2002). The threshold of humidity and exposure time for spore germination is higher in materials stone-based than wood-based (Ritschkoff, Viitanen and Koskela, 2000). Therefore, construction products made from mineral and ceramics which contain less organic matter should be selected with priority (Johansson, 2014). Mould can even appear on the mould-resistant material which is contaminated by organic dust (Chang, Foarde and VanOsdell, 1996). To avoid this problem, nonporous and low-texture materials that cannot harbour dust or nutrients are preferred (Warsco and Lindsey, 2003). 
Under their mould-resistant abilities, Sedlbaver (2001 b) categorised substrates into four classes. Most of the construction materials belong to Category Two which are biologically adverse recyclable. China also has issued related standards on the mould issue of three construction products. Based on their mould resistance, there are two different levels for building sealants, five levels for wooden decoration boards and also five levels for building painting productions. When architects do the decision makings on material designation, these indexes should be considered.

\section{Ventilation, Air Conditioning and Pressurisation (VACP)}

The VACP design is not architects' direct duty but it should be known for their role as a design team leader. The indoor dampness and mould risk are strongly related to ventilation (Moon and Augenbroe, 2004; Hens, 1999), which can remove or dilute the air moisture and also exhaust airborne spores or contaminants (Warsco and Lindsey, 2003). Due to no central HVAC system in most buildings across the Yangtze River Delta, only stack and wind-induced ventilation can be applied to. However, during the Plum Rain Season, windows are usually closed thence even the natural ventilation is difficult to obtain. After three years measuring, eight out of 10 homes in Shanghai only with natural ventilation were found to have a ventilation rate lower than $0.5 \mathrm{~h}^{-1}$ (Wang, 2007). There is no successful case which solely utilises passive ventilating strategies. For buildings in the Yangtze River Delta, only mechanical or half-mechanical ventilation system can be helpful (Wang, 2007).

During the summer period in Yangtze River Delta, the majority of homes use domestic air-conditioners for cooling which also can extract the moisture out of the room. When the air is cooled and the RH becomes 100\%, the moisture will condense on the cooling coils because the air is unable to hold more water vapour. At the same time, many domestic air-conditioners have mould inside but it receives even less attention compared with indoor mould on the wall. Appropriate sizing of air conditioners becomes necessary to reduce the mould risk (Warsco and Lindsey, 2003).

The pressurisation is another way to keep moisture out by the positive pressure between indoor and outside (Chen et al., 2016). Nevertheless, this method is only useful for a limited space rather than a whole building because static pressures in the same building differ from one space to another, due to the stack effect and the HVAC operation (ASHRAE, 2009). Meanwhile, except the fire escape staircase in high-rise buildings which utilise the pressurisation to keep out smoke for evacuation, other common buildings do not have any pressurisation facilities. It is not applicable to popularise this approach.

\section{Landscape Design}

Landscape design also plays a role in lowering the mould risk. No need for daily watering nor releasing much water molecules, Xeriscape (drought-tolerant plants) can help buildings escape the excessive moisture load (Harriman and Neil, 2006). On the other hand, the fountain or pool can be avoided in extremely moist areas. Meanwhile, the mould-spore concentration rate in the greened room is lower than not greened one (Fantucci et al., 2017). With the help of new tech, a living wall system can be utilised not only outside but also indoor. 


\section{Matrix for the Decision Making}

This tries to embed all strategies in different design steps and make a guiding matrix (as shown in Figure 9) for architects. According to the Chinese code "Standard of Design Depth in Construction Documentation" (Ministry of Housing and Urban-Rural Development, 2016), the design phase of common projects can be divided into the concept and schematic design, development design and construction-document design. The matrix chronologically follows this sequence while categorising strategies from previous section. Although this matrix follows the Chinese code, it still can be applied to projects in other countries with little change because these stage divisions are more or less the same in different countries. For example, by the American Institute of Architects (AIA), one design project is similarly divided into programming, schematic design, design development and preparation of construction documents.

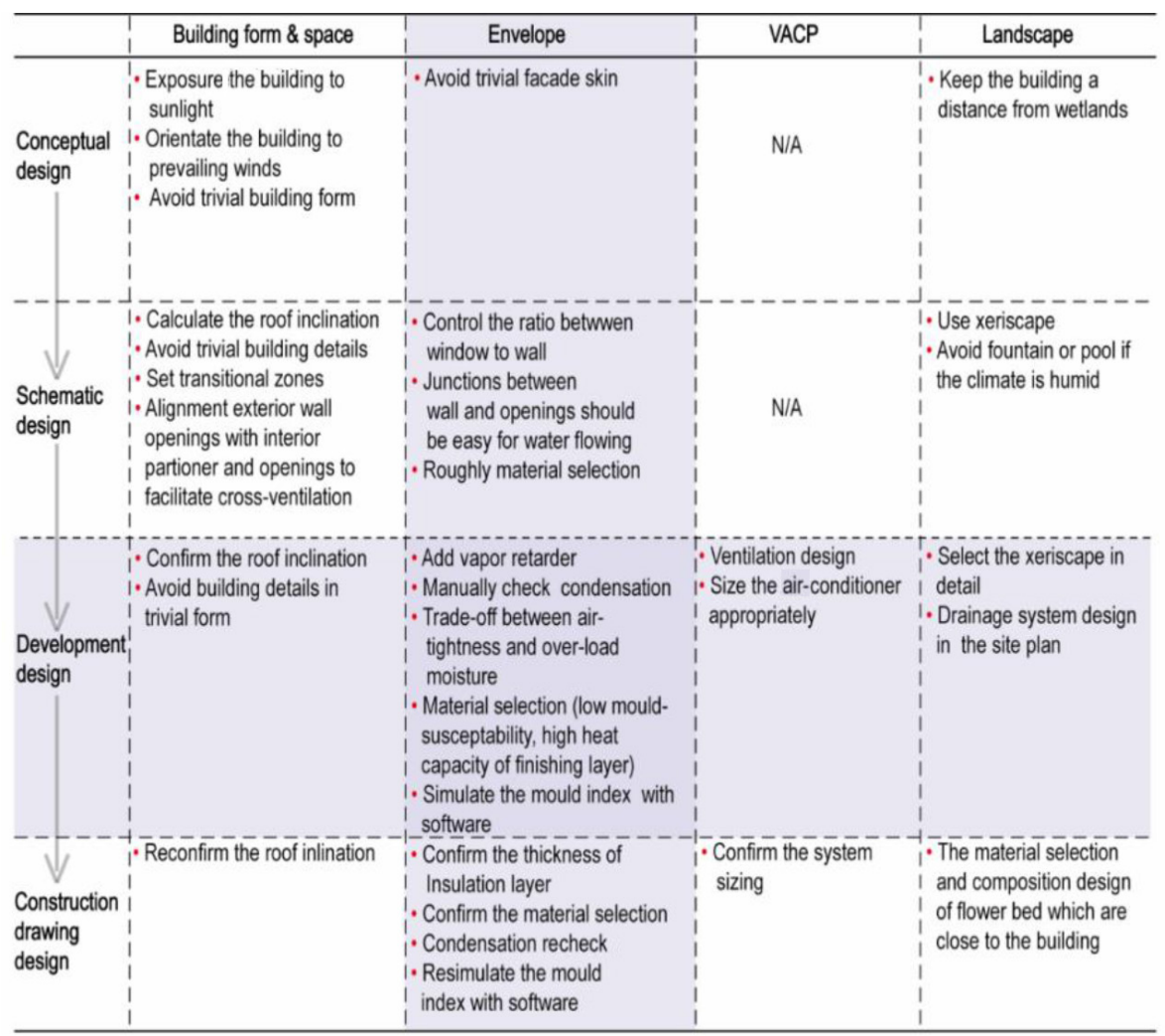

Figure 9. Matrix Reducing Mould Risk During the Whole Design Process 


\section{CONCLUSION}

Although the indoor mould problem broadly exists over the Yangtze River Delta, rare attention has been paid to prevent it. There is a vast need for associated research and policies to address this issue. With computational simulation, the indoor mould risk across that region (Hangzhou, Shanghai and Nanjing) was quantified. Simulation results confirmed that all three cases have a high mould risk, especially Shanghai. The south-east is the most vulnerable direction for three cities: Hangzhou has a maximum mould growth rate of $296 \mathrm{~mm}$ per year, Nanjing has the rate around 273 $\mathrm{mm}$ per year and Shanghai reaches $438 \mathrm{~mm}$ per year. The real situation is even worse because this simulation was conducted in a steady-state condition.

After obtaining the mould risk scenario, variables related to the mould risk were analysed and it is found that only the humidity and the substrate properties can be practically tuned to prevent the mould. Subsequently, this article scrutinised and categorised all the design strategies. In the end, a design strategy matrix identifying all chances during the whole design stage was presented. The matrix showed that the development design stage is the most important period for mould prevention while the envelope design has more opportunities to reduce the mould risk.

The current study also has many limitations. Firstly, there is no on-site data to validate the simulation. Secondly, the simulation only deals with the wall rather than a whole building. Thirdly, due to the second point, authors are unable to use simulation to confirm the usefulness of design strategies from the third section. However, due to limited studies considering the mould risk during the design stage, this article is still beneficial in raising awareness of the relationship between building design and the mould risk.

\section{REFERENCES}

American Society of Heating, Refrigerating and Air-Conditioning Engineers (ASHRAE) (2012). ASHRAE Position Document on Limiting Indoor Mold and Dampness in Buildings. Georgia, USA: ASHRAE.

(2009). Indoor Air Quality Guide. Georgia, USA: ASHRAE.

Baidu.com (2016). 梅雨季节 [Plum season]. Available at: http://baike.baidu.com/ item/梅雨季节/32325 [Accessed on 15 May 2020].

Chang, J.C.S., Foarde, K.K. and VanOsdell, D.W. (1996). Assessment of fungal (Penicillium chrysogenum) growth on three HVAC duct materials. Environment International, 22(4): 425-431. https://doi.org/10.1016/0160-4120(96)00030-X.

Chen, W.J., Claridge, D.E., Rohrs, C. and Liao, J. (2016). Modeling to predict positive pressurization required to control mold growth from infiltration in buildings in a hot and humid climate. Building and Environment, 104: 102-113. https://doi.org/10.1016/j.buildenv.2016.05.001.

Elisa, G. (2013). Nearly Zero Energy Buildings and Proliferation of Microorganisms. Cham, Switzerland: Springer.

Fantucci, S., Isaia, F., Serra, V. and Dutto, M. (2017). Insulating coat to prevent mold growth in thermal bridges. Energy Procedia, 134: 414-422. https://doi.org/10.1016/j.egypro.2017.09.591.

Fraunhofer Building Innovation (2017). WUFI ${ }^{\circledR}$ BIO. Available at: https://wufi.de/ en/2017/03/31/wufi-bio/ [Accessed on 15 May 2020]. 
General Office of the State Council (2007). 国务院办公厅关于严格执行 公共建筑空 调温度控制标准的通知 [Notification of Temperature Control Standards for Air Conditioning in Public Buildings]. Beijing: General Office of the State Council. Available at: http://www.gov.cn/xxgk/pub/govpublic/mrlm/200803/t20080 328_32576.html [Accessed on 15 May 2020].

Häglund, M., Isaksson, T. and Thelandersson, S. (2010). Onset of mould growth: The effect of climate variability and different geographic locations. IRG 10-20446. Paper presented at the Conference IRG 41. Biarritz, France, 9-13 May.

Harriman, L. and Neil, L. (2006). California Builder's Guide to Reduce Mold Risk. Des Plaines, CA: Gas Technology Institute.

Hens, H. (2003). Mold in dwellings: Field studies in a moderate climate. Proceedings of the 24th AIVC Conference and BETEC Conference, Ventilation, Humidity Control and Energy. Washington DC: Air Infiltration and Ventilation Centre (AIVC), 12-14. Available at: https://bwk.kuleuven.be/bwf/projects/annex41/ protected/data/KUL\%20Apr\%202006\%20Paper\%20A41-T4-B-06-5.pdf [Accessed on 15 May 2020].

(1992). IEA Annex 14: Condensation and energy. Journal of Thermal Insulation, 15(3): 261-273. https://doi.org/10.1177/109719639201500307.

Hens, H.L.S.C. (1999). Fungal defacement in buildings: A performance related approach. HVAC\&R Research, 5(3): 265-280. https://doi.org/10.1080/107896 69.1999.10391237.

Hyvärinen, A., Meklin, T., Vepsäläinen, A. and Nevalainen, A. (2002). Fungi and actinobacteria in moisture-damaged building materials: Concentrations and diversity. International Biodeterioration and Biodegradation, 49(1): 27-37. https://doi.org/10.1016/S0964-8305(01)00103-2.

Jiangsu Provincial Office for Construction Engineering Standards (2006). HR 保温装饰 板外保温系统 [External Insulation System with HR Decorative Insulation Board]. Nanjing: Jiangsu Provincial Office for Construction Engineering Standards. Available at: http://183.61.19.162/zdoc/苏JT16-2006(五) 建筑外保温构造图集 (五) HR保温装饰板外保温系统.pdf [Accessed on 15 May 2020].

Johansson, P. (2014). Determination of the critical moisture level for mould growth on building materials. PhD diss., Lund University.

Johansson, S., Wadsö, L. and Sandin, K. (2010). Estimation of mould growth levels on rendered façades based on surface relative humidity and surface temperature measurements. Building and Environment, 45(5): 1153-1160. https://doi.org/10.1016/j.buildenv.2009.10.022.

- (2005). Microbial growth on buildings facades with thin rendering on thermal insulation. In 7th Nordic Building Physics Symposium in Reykjavik. Reykjavik, Iceland: Division of Building Materials, Lund University.

Karagiozis, A. and Hadjisophocleous, G. (1995). Wind-driven rain on high-rise buildings. Buildings VI Proceedings. Oak Ridge, TN: Oak Ridge National Laboratory (ORNL), 399-406. Available at: https://web.ornl.gov/sci/buildings/ conf-archive/1995\%20B6\%20papers/044_Karagiozis.pdf [Accessed on 15 May 2020].

Khan, A.A.H. and Karuppayil, S.M. (2012). Fungal pollution of indoor environments and its management. Saudi Journal of Biological Sciences, 19(4): 405-426. https://doi.org/10.1016/j.sjbs.2012.06.002. 
Ministry of Housing and Urban-Rural Development (MOHURD) (2016). 建筑工程设计文 件编制深度规定 [Regulation on the Depth of Construction Engineering Design Documents]. Beijing: MOHURD. Available at: http://www.mohurd.gov.cn/ wjfb/201612/†20161201_229701.html [Accessed on 15 May 2020].

—. (2010). 夏热冬冷地区居住建筑节能设计标准 [Design Standard for Energy Efficiency of Residential Buildings in Hot Summer and Cold Winter Zone]. Beijing: MOHURD. Available at: http://www.jianbiaoku.com/webarbs/ book/412/2592432.shtml [Accessed on 15 May 2020].

Mlakar, J. and Štrancar, J. (2013). Temperature and humidity profiles in passive-house building blocks. Building and Environment, 60: 185-193. https://doi.org/10.1016/j.buildenv.2012.11.018.

Møller, E.B., Andersen, B., Rode, C. and Peuhkuri, R. (2017). Conditions for mould growth on typical interior surfaces. Energy Procedia, 132: 171-176. https://doi.org/10.1016/j.egypro.2017.09.680.

Moon, $\mathrm{H}$. and Augenbroe, G. (2004). Future research needs for mold growth risk analysis. In CIB World Building Congress 2004, Building for the Future Building for the Future. Ontario, Canada: National Research Council of Canada, 1-10. Available at: https://www.irbnet.de/daten/iconda/CIB1772.pdf [Accessed on 15 May 2020].

Moon, H.J. and Augenbroe, G. (2003). Evaluation of hygrothermal models for mold growth avoidance prediction. Paper presented at the Eighth International IBPSA Conference. Eindhoven, Netherlands, 11-14 August.

Nunez, M. and Hammer, H. (2014). Microbial specialists in below-grade foundation walls in Scandinavia. Indoor Air, 24(5): 543-551. https://doi.org/10.1111/ ina.12095.

Orlik-Kozdoń, B. and Steidl, T. (2017). Impact of internal insulation on the hygrothermal performance of brick wall. Journal of Building Physics, 41 (2): 120-134. https:// doi.org/10.1177/1744259116671322.

Ritschkoff, A.C., Viitanen, H. and Koskela, K. (2000). The response of building materials to the mould exposure at different response conditions. In Healthy Buildings 2000: Proceedings; Vol. 1, Exposure, Human Responses and Building Investigations. Helsinki: SIY Indoor Air Information Oy, 317-322.

Rose, W.B. (2005). Water in Buildings: An architect's Guide to Moisture and Mold. Hoboken, NJ: Wiley.

Sedlbaver, K. (2001a). Prediction of Mould Fungus Formation on the Surface of/and inside Building Components. München, Germany: Fraunhofer Institute. Available at: http://www.ibp.fraunhofer.de/content/dam/ibp/en/ documents/ks_dissertation_etcm 1021-30729.pdf [Accessed on 15 May 2020].

—. (2001 b). Vorhersage von schimmelpilzbildung auf und in bauteilen [Prediction of mold formation on and in construction units]. PhD diss., Universität Stuttgart.

Shanghai Commission of Urban and Rural Construction and Transportation (2013). 装配整体式混凝土住宅构造图集 [Atlas of the Assembled Monolithic Residential Structures]. Shanghai: Shanghai Commission of Urban and Rural Construction and Transportation. Available at: https://wenku.baidu.com/ view/3f08214f998fcc22bcd10dca.html [Accessed on 15 May 2020].

Trechsel, H. and Bomberg, M.T. (2010). Moisture Control in Buildings: The Key Factor in Mold Prevention. 2nd Ed. Philadelphia, PA: ASTM International.

United States Environmental Protection Agency (US EPA) (2013). Moisture Control Guidance for Building Design, Construction and Maintenance. Washington DC: US EPA. 
(2012). A Brief Guide to Mold, Moisture and Your Home. Washington DC: US EPA.

Vereecken, E. and Roels, S. (2012). Review of mould prediction models and their influence on mould risk evaluation. Building and Environment, 51 (April): 296310. https://doi.org/10.1016/j.buildenv.2011.11.003.

Viitanen, H. and Ritschkoff, A. (1991). Mould Growth in Pine and Spruce Sapwood in Relation to Air Humidity and Temperature. Uppsala, Sweden: Swedish University of Agricultural Sciences.

Viitanen, H., Vinha, J., Salminen, K., Ojanen, T., Peuhkuri, R., Paajanen, L. and Lahdesmaki, K. (2010). Moisture and bio-deterioration risk of building materials and structures. Journal of Building Physics, 33(3): 201-224. https:// doi.org/10.1177/1744259109343511.

Wang，Z. (2007). 机械通风是解决中国住宅室内通风问题的最佳方法 [Mechanical ventilation is the best way to solve the ventilation problem in Chinese residential buildings]. In 2007年中日可持续发展建筑技术与产品交流会论文集 [Proceedings of the 2007 China-Japan Sustainable Construction Technology and Product Exchange Conference]. Beijing: China Academy of Building Research. Available at: http://www.wanfangdata.com.cn/details/detail. do?_type $=$ conference\&id=6575840 [Accessed on 15 May 2020].

Warsco, K. and Lindsey, P.F. (2003). Proactive approaches for mold-free interior environments. Archives of Environmental Health, 58(8): 512-22. https://doi.org/10.3200/AEOH.58.8.512-522.

Wei, X. (2016). 上海市居住建筑室内墙体表面霉菌生长调研 [Study on mould growth in dwelling building of Shanghai]. 建筑热能通风空调 [Building Energy and Environment], 35(1): 27-30.

Zhejiang Provincial Department of Housing and Urban-Rural Development (2013). 轻质混凝土砖墙体节能与结构一体化构造 [Integral Structure and Energy Saving of Lightweight Concrete Block Wall]. 1st Ed. Hangzhou: Zhejiang Gongshang University Press. Available at: https://ebook.chinabuilding.com.cn/zbooklib/ bookpdf/probation?SitelD=1 \&bookID=103828 [Accessed on 15 May 2020]. 